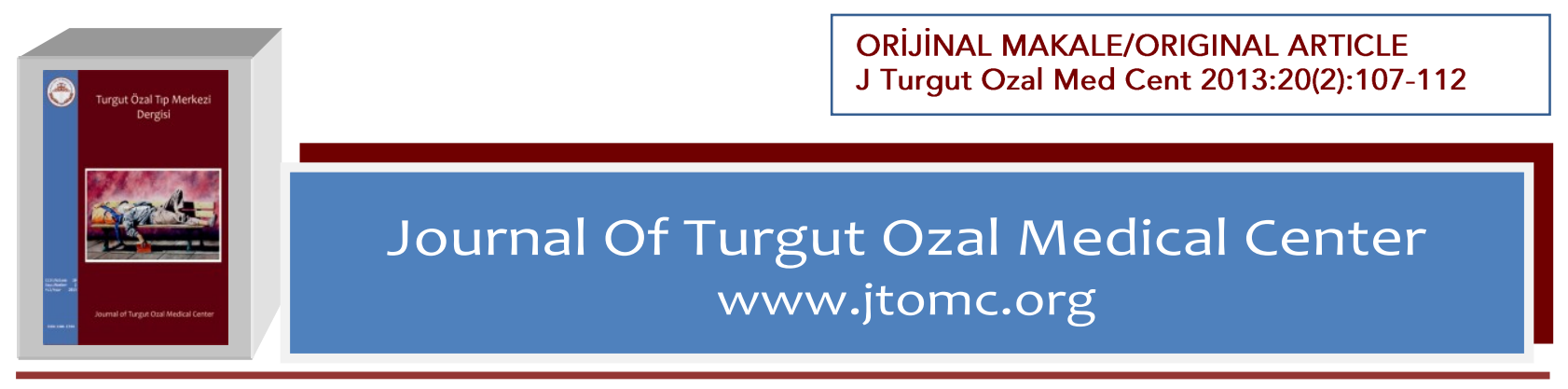

\title{
A Prospective Case-Controlled Study of Endothelial Function in Patients with Mild to Moderate Psoriasis
}

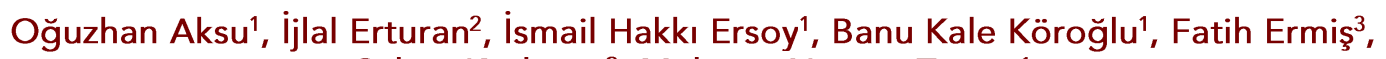 \\ Selma Korkmaz ${ }^{2}$, Mehmet Numan Tamer ${ }^{1}$
}

\author{
'Süleyman Demirel Üniversitesi Tıp Fakültesi, Endokrinoloji ve Metabolizma Hastalıkları Bilim Dalı, Isparta, \\ Türkiye \\ 2Süleyman Demirel Üniversitesi Tıp Fakültesi, Dermatoloji Anabilim Dalı, Isparta, Türkiye \\ ${ }^{3}$ Düzce Üniversitesi Tıp Fakültesi, Gastroenteroloji Bilim Dalı, Düzce, Türkiye
}

\begin{abstract}
Aim: The aim of this study is to investigate endothelial dysfunction in psoriasis patients with non-invasive methods.

Materials and Methods: Fifty-three psoriasis patients and 53 healthy individuals were included in the study. Carotid artery intimae-media thickness and brachial artery flow-mediated dilation was measured both in patient and control groups.

Results: Mean age, gender, body mass index, smoking habits, anthropometric measurements and arterial blood pressure values were similar in both groups. Mean psoriasis area and severity index score of psoriasis patients was $6.35 \pm 6.81$. Triglyceride level was significantly higher $(p<0.05)$ and high density lipoprotein cholesterol level was significantly lower $(p<0.05)$ in psoriasis patients when compared with the controls. Insulin resistance was found to be statistically higher in psoriasis patients group than the control group $(p<0.05)$. There was no significant differences between two groups in terms of carotid artery intimae-media thickness $(p>0.05)$; but flow-mediated dilation was found to be statistically significantly lower in psoriasis patients than the control group $(p<0.05)$. FT3 level was also found to be statistically significantly lower in psoriasis patients than the control group $(p=0.05)$.

Conclusion: This study showed endothelial dysfunction and insulin resistance in psoriasis patients with low disease activity even in the absence of clinical cardiovascular disease. Thyroid function tests could supply information about cardiovascular risk.

Key Words: Psoriasis; Endothelial Dysfunction; Free T3.

Hafif-Orta Psöriyazisli Hastalarda Endotel Fonksiyonlarının ProspektifVaka Kontrollü Değerlendirilmesi

Özet

Amaç: Bu çalışmanın amacı orta derecede psöriyazisi olan hastalarda endotelyel disfonksiyonu varlığınıinvaziv olmayan yöntemlerle araştırmaktır.

Gereç ve yöntemler: Elli üç psöriyazisli hasta ve 53 sağlıklı birey çalışmaya dâhil edildi. Çalışmaya dahil edilen tüm hasta ve kontrol grubunun karotid arter intima-medya kalınlığı ve brakiyal arterin akım aracılı dilatasyonu ölçüldü.

Bulgular: Çalışmaya dahil edilen tüm hastaların ortalama yaş, cinsiyet, vücut kitle indeksi, sigara alışkanlığı, antropometrik ölçümler ve arteryel kan basınçlarının hem psöriyazisli hasta hem de kontrol grubunda benzer olduğu görüldü. Hasta grubu değerlendirildiğinde ortalama psöriyazis alanı ve şiddet indeks skorunun $6.35 \pm 6.81$ olduğu görüldü. Kontrol grubu ile karşılaştırıldığında hasta grubunda trigliserid seviyesi anlamlı olarak daha yüksekti $(p<0.05)$, lipoprotein kolesterol seviyesi ise anlamlı olarak daha düşüktü $(p<0.05)$. Hasta grubunda insülin direnci kontrol grubuna oranla istatistiksel olarak daha yüksek bulundu $(p<0.05)$. Hem psöriyazisli hasta grubunda hem de kontrol grubunda karotid arter intima-medya kalınlığı açısından anlamlı bir fark yoktu ( $p>0.05$ ); ancak akım aracılı dilatasyonu hasta grubunda kontrole oranla istatistiksel olarak daha düşük bulundu $(p<0.05)$. Serbest T3 seviyesi de hasta grubunda kontrol grubuna göre istatistiksel olarak daha düșük bulundu $(p<0.05)$.

Sonuçlar: Bu çalışma ile düşük aktiviteli psöriyatik hastalarda, klinik olarak kardiyovasküler hastalık saptanmamıs olsa bile endotelyel disfonksiyonunun olabileceğini gösterilmiştir. Ayrıca bu çalışma ile psöriyatik hasta grubunda insülin direncininin olduğu da gösterilmiştir. Tiroid fonksiyon testleri kardiyovasküler risk hakkında ilave bilgi sağlayabilir.

Anahtar Kelimeler: Psoriyazis; Endotelyel Disfonksiyon; Ötroid Hasta Sendromu.
\end{abstract}

\section{INTRODUCTION}

Psoriasis disease is chronic, recurrent, inflammatory disorder of unknown etiology which is characterized with red squamous plaques in the extensor surfaces of the body (1). It is estimated that $2-3 \%$ of the world population was affected by this disease (2). After having understood the role of inflammation in the pathogenesis of psoriasis, it strengthened the belief that psoriasis was a systemic inflammatory disease process rather than a skin lesion $(3,4)$. Cardiovascular disease is one of the important morbidity and mortality cause in psoriasis patients. Besides myocardial infarction, cardiovascular disease risk is more common in psoriasis patients and it increases as the severity of the disease increases (5). Although there are some studies which show psoriasis is an independent risk factor for cardiovascular disease (6), some studies do not support this hypothesis (7-9). 
Precaution must be taken before the emergence of clinical atherosclerotic events. Therefore, display of early atherosclerotic changes is very important to reduce these risk factors. The most important changes during the period of subclinical atherosclerotic disease are the increase in the intima media thickness and endothelial dysfunction seen in all arterial beds (10). Endothelial dysfunction is an indicator of vascular involvement in any disease which affects vascular tissue. It may be related with vascular interaction in psoriasis disease.

We aimed to investigate endothelial dysfunction in psoriasis patients with non-invasive methods and thus to provide early detection of atherosclerotic lesions and to guide medical treatment.

\section{MATERIAL AND METHODS}

Fifty-three psoriasis patients and fifty-three healthy controls were enrolled in this study. The controls were selected from healthy individuals who applied to hospital outpatient clinic for general health checkup. All participants signed informed consent form and the study protocol which was compatible with Helsinki declaration that was approved by the local ethics committee.

Psoriasis was diagnosed clinically. The current disease severity was evaluated by using the psoriasis area and severity index (PASI). Head, trunk, upper and lower extremities were considered separately according to PASI. Erythema, infiltration and desquamation were scored between 0 to 4 in each four sites. Then scores; patients with PASI score between 0.1 to 10.9 was accepted as mild and 11 to 49.9 as moderate.

Diabetes mellitus (fasting venous plasma glucose concentration $>110 \mathrm{mg} / \mathrm{dL}$ ), hypertension (systolic blood pressure $>140 \mathrm{mmHg}$ or diastolic blood pressure $>90 \mathrm{mmHg}$ ), cardiovascular, cerebrovascular, and those with a history of atherosclerotic disease and renal failure (serum creatinine $>1.3 \mathrm{mg} / \mathrm{dl}$ ) were excluded from the study. Patients who received lipid-lowering therapy, antihypertensive or antiaggregant treatment, nitrates and long-acting steroid therapy were also excluded from the study.

Disease duration, patients' age at onset of the disease and treatments they received and smoking status were recorded. Participants who smoked at least once a day since last year were included in the smoking group and those who never smoked and who quit smoking at least 5 years ago were included in the non-smokers group. Waist and hip circumferences of all study participants were measured and waist-hip ratios were calculated. Body mass index (BMI) is calculated by dividing the weight in kilograms by the square of the height in meters (the units are $\mathrm{kg} / \mathrm{m}^{2}$ ).

Laboratory examination:

Blood samples were drawn from participants after 12hour fasting state through the antecubital vein in order to assess complete blood count, sedimentation rate, high sensitivity c? reactive protein (hsCRP), glucose, blood urea nitrogen (BUN), creatinine, uric acid, alanine aminotransferase (ALT), aspartate aminotransferase (AST), total cholesterol, triglyceride (TG), high density lipoprotein cholesterol (HDL), low density lipoprotein cholesterol (LDL), insulin, FreeT3, FreeT4, thyroid stimulating hormone (TSH). Complete blood count was evaluated by flow cytometry method in Bekman Coulter LH 750 analyzer and sedimentation rate was determined by Westergren method. Glucose, total cholesterol, TG, HDL, LDL, BUN, creatinine, ALT, AST, uric acid were evaluated by spectrophotometric method in Olympus AV 2700 autoanalyzer. ?hsCRP was evaluated by atomic absorption spectrometer in Perkin Elmer Analist 800. FT3, FT4, TSH were determined by electrochemiluminescent immunoassay method in DXI 800 Berkman Coulter. Insulin level was determined by electrochemiluminescent immunoassay method (Immulite 2000). Insulin resistance (IR) was calculated by Homeostasis Model Assessment (HOMA) index. HOMA-IR is determined by the following formula: HOMA-IR= fasting plasma immunoreactive insulin (IRI; $\mu \mathrm{U} / \mathrm{mL}$ ) $X$ fasting plasma glucose (FBG; mg/dL) /405. HOMA-IR values $>2.7$ were considered to indicate insulin resistance (11).

Ultrasonographic evaluation:

For the measurement of carotid artery intima-media thickness (CIMT) and brachial artery flow-mediated dilation (FMD), an ultrasound device (SDU Schimadzu XPlus 2200) was used which had 2-dimensional image property and a high-resolution $(0.01 \mathrm{~mm}$ in thicknesssensitive), color, spectral Doppler and broad-band linear probe from 7 to $12.5 \mathrm{MHz}$. SDU Schimadzu XPlus 2200 also had a physiological unit that allows internal ECG monitorization.

Measurements were performed 8-12 hours after a 12hour fasting state, at room temperature in a quiet, dark room after 20 minutes of supine position rest by the same observer. In addition, all participants warned not to exercise, use caffeine and vitamin C that may affect FMD and not to smoke before the procedure. After rest at $24{ }^{\circ} \mathrm{C}$ for 10 minutes at room temperature in the supine position, blood pressure was measured from right arm and then connected to device for electrocardiography (ECG) monitoring. Participant's left arm supported by a table in order to stay still, elbow and forearm were put in extension position to see brachial artery. Brachial artery pulses were palpated $2-5 \mathrm{~cm}$ proximal to the antecubital fossa, then brachial artery viewed in longitudinal position with B-mode superficial probe and Doppler 
images were displayed. Artery diameter was measured during R-wave simultaneously during ECG monitoring. This measurement was recorded as basal artery diameter. For the second measurement as the lower end of sphygmomanometer's cuff placed at the wrist, it was inflated $50 \mathrm{mmHg}$ higher than systolic blood pressure and remained in the same pressure for 5 minutes. Forty-five to sixty seconds after lowering the cuff re-measurement of arterial diameter was performed as described above. Percent dilatation between baseline measurement after dilatation and/or flow-mediated dilation was calculated by taking the absolute difference. After temporary ischemia brachial artery diameter's FMD measurement was used for detection of endothelial dysfunction.

Segment just before carotid artery bifurcation was viewed in longitudinal position with B-mode superficial probe and Doppler images were displayed. ECG monitoring was done simultaneously with the $R$ wave on both sides of the wall of the artery at the time of a double hyperechoic (white) lines. Thickness between these two lines was determined as CIMT. CIMT measurements repeated 3 times far from the probe and the average was measured. After projection of the probe signed, all measurements were taken from the same place. All ultrasonographic measurements were performed by the same physician unaware of both groups.

Statistical analysis:

SPSS 15 version for windows package program (Chicago, IL, USA) was used for all statistical analysis. Continuous variables were expressed as mean \pm standard deviation (SD), categorical variables were expressed as percentage or rate. Compliance with the normal distribution of variables was assessed with Kolmogorov-Smirnov test. Unpaired t-test was used for normally distributed continuous variables and Mann-Whitney $U$ test used for continuous variables without normal distribution. Chi-square test was performed for qualitative variables. Relationships between the parameters were evaluated by Pearson's correlation analysis. The calculated $p$-value $<0.05$ was considered statistically significant.

\section{RESULTS}

The study consisted of a total 106 participants. Participants' demographic, clinical, and laboratory values were shown in Table 1. Mean age of psoriasis group was $37.66 \pm 15.61$ years and the mean age of control group was $35.77 \pm 15.11$ years $(p<0.05)$. Mean disease duration of the psoriasis group was $118.31 \pm 130.93$ months. Average age of disease onset was $26.07 \pm 13.34$ years. Average PASI value of psoriasis patients was determined as $6.35 \pm 6.81$. Thirty-six $(67.9 \%)$ psoriasis patients received topical therapy, $4(7.5 \%)$ of them received only systemic treatment, $12(22.6 \%)$ received both topical and systemic treatment, but $1(1.9 \%)$ patient had no treatment at all.

Mean age, gender, BMI, arterial blood pressure and anthropometric measurements were similar in both psoriasis and control groups ( $p>0.05$ ). Routine biochemical examination, complete blood count, glucose, sedimentation rate, uric acid, liver and kidney function tests were not statistically significant different between two groups, Triglyceride level was significantly higher $(p<0.05)$ and HDL level was significantly lower $(p<0.05)$ in psoriasis patients when compared with the controls. Although hsCRP level was higher in psoriasis group, but difference was not statistically significant ( $p>0.05)$.

FT3 level was found to be statistically lower in psoriasis patients than the control group ( $p<0.05$ ). FT4 and TSH levels were similar in both groups (Table 1). Insulin resistance was found to be statistically higher in psoriasis patients group than the control group $(p<0.05)$. There was no significant difference between the two groups in terms of CIMT ( $p>0.05)$, but brachial artery FMD was found to be statistically significant lower in psoriasis patients than the control group ( $p<0.05)$ (Table 2 ).

Insulin resistance showed negative correlation with glucose, uric acid, triglyceride, LDL, hsCRP, BMI, waist circumference and waist-hip ratio in spearmen analysis. There was a strong positive correlation between CIMT and age $(r=0.626)$. CIMT was positively correlated with glucose, BUN, sedimentation rate, hsCRP, BMI, waist circumference, waist-hip ratio, systolic blood pressure. CIMT was negatively correlated with FT3, TSH, and FMD.

Basal artery diameter was strongly correlated with flow-mediated dilatation ( $r=0.929)$; and basal artery diameter was strongly correlated with haemoglobin level $(r=0,517)$. There was a positive correlation between basal artery diameter with age, BUN, creatinine, ALT, AST, uric acid, triglyceride, BMI, waist circumference, waist-hip ratio, systolic and diastolic blood pressure and CIMT in FMD. In FMD, basal artery diameter was negatively correlated with $\mathrm{HDL}$, sedimentation rate, TSH and the percentage of flow-mediated dilatation. There was a strong positive correlation between the control value of FMD and hemoglobin $(r=0.528)$ while there was just a positive correlation between the control value of FMD and age, BUN, creatinine, ALT, AST, uric acid, triglyceride, $\mathrm{BMI}$, waist circumference, waist-hip ratio, systolic blood pressure. There was a negative correlation with control value of FMD and HDL, sedimentation rate, TSH. Percentage (\%) of FMD was positively correlated with HDL while it was negatively correlated with uric acid, triglyceride, CIMT and basal artery diameter in FMD. 
Table 1. Demographic, clinical and laboratory values of patients and control groups

\begin{tabular}{|c|c|c|c|}
\hline Variables & $\begin{array}{l}\text { Patient group }(n=53) \\
\text { Mean } \pm \text { SD or } \%\end{array}$ & $\begin{array}{c}\text { Control group }(n=53) \\
\text { Mean } \pm \text { SD or } \%\end{array}$ & $\mathbf{p}$ \\
\hline Age (years) & $37.66 \pm 15.61$ & $35.77 \pm 15.11$ & 0.529 \\
\hline Gender F/M & $30 / 23(\% 56.6-23.4)$ & $25 / 28(\% 47.2-52.8)$ & 0.331 \\
\hline Length (cm) & $168.66 \pm 10.97$ & $165.98 \pm 10.58$ & 0.204 \\
\hline Weight(kg) & $75.07 \pm 15.11$ & $72.73 \pm 12.26$ & 0.384 \\
\hline $\mathrm{BMI}\left(\mathrm{kg} / \mathrm{m}^{2}\right)$ & $26.30 \pm 4.91$ & $26.55 \pm 4.63$ & 0.796 \\
\hline Waist circumference $(\mathrm{cm})$ & $94.00 \pm 12.39$ & $96.66 \pm 12.05$ & 0.265 \\
\hline Hip circumference $(\mathrm{cm})$ & $104.03 \pm 8.05$ & $106.50 \pm 8.20$ & 0.121 \\
\hline Waist-hip ratio & $0.89 \pm 0.07$ & $0.87 \pm 0.10$ & 0.234 \\
\hline Systolic arterial pressure $(\mathrm{mmHg})$ & $115.84 \pm 11.67$ & $116.22 \pm 11.08$ & 0.514 \\
\hline Diastolic arterial pressure $(\mathrm{mmHg})$ & $73.77 \pm 7.89$ & $73.49 \pm 8.00$ & 0.989 \\
\hline WBC $\left(/ \mathrm{mm}^{3}\right)$ & $8.67 \pm 7.22$ & $7.73 \pm 2.11$ & 0.467 \\
\hline $\mathrm{HGB}(\mathrm{g} / \mathrm{dl})$ & $14.70 \pm 1.69$ & $14.56 \pm 1.66$ & 0.665 \\
\hline $\operatorname{PLT}\left(/ \mathrm{mm}^{3}\right)$ & $253.45 \pm 5.89$ & $242.69 \pm 61.19$ & 0.359 \\
\hline Urea (mg/dl) & $12.40 \pm 3.12$ & $12.47 \pm 4.56$ & 0.925 \\
\hline Creatinine ((mg/dl) & $0.94 \pm 0.17$ & $0.95 \pm 0.18$ & 0.792 \\
\hline ALT (IU/ml) & $30.30 \pm 35.37$ & $21.20 \pm 10.14$ & 0.187 \\
\hline AST (IU/ml) & $26.13 \pm 16.70$ & $21.60 \pm 8.00$ & $0.034^{\star}$ \\
\hline Uric acid (mg/dl) & $4.95 \pm 1.22$ & $4.60 \pm 1.12$ & 0.134 \\
\hline Total cholesterol (mg/dl) & $184.43 \pm 48.80$ & $182.94 \pm 41.93$ & 0.866 \\
\hline Triglyceride (mg/dl) & $137.86 \pm 69.01$ & $111.3 \pm 58.13$ & $0.047^{\star}$ \\
\hline $\mathrm{HDL}(\mathrm{mg} / \mathrm{dl})$ & $46.83 \pm 10.45$ & $51.07 \pm 9.51$ & $0.031 *$ \\
\hline LDL (mg/dl) & $106.78 \pm 44.08$ & $106.90 \pm 33.05$ & 0.987 \\
\hline Sedimentation $(\mathrm{mm} / \mathrm{h})$ & $13.64 \pm 16.02$ & $12.33 \pm 13.78$ & 0.773 \\
\hline $\mathrm{HsCRP}$ (mg/l) & $5.29 \pm 12.41$ & $3.09 \pm 6.68$ & 0.099 \\
\hline FT3 (pg/ml) & $3.15 \pm 0.33$ & $3.32 \pm 0.30$ & $0.004^{\star}$ \\
\hline FT4 (ng/dl) & $0.81 \pm 0.15$ & $0.84 \pm 0.15$ & 0.218 \\
\hline $\mathrm{TSH}(\mathrm{ulU} / \mathrm{ml})$ & $1.84 \pm 1.79$ & $1.50 \pm 1.27$ & 0.093 \\
\hline
\end{tabular}

Table 2. Insulin resistance and ultrasonographic measurements of patients and control groups

\begin{tabular}{lccc}
\hline \multicolumn{1}{c}{ Variables } & $\begin{array}{c}\text { Patient group (n=53) } \\
\text { Mean } \pm \text { SD or } \%\end{array}$ & $\begin{array}{c}\text { Control group }(\mathbf{n}=53) \\
\text { Mean } \pm \text { SD or } \%\end{array}$ & $\mathbf{p}$ \\
\hline Glucose (mg/dl) & $93.16 \pm 17.09$ & $95.37 \pm 12.57$ & 0.124 \\
Insulin (mU/L) & $12.11 \pm 13.55$ & $9,16 \pm 7.30$ & 0.390 \\
HOMA & $2.88 \pm 3.54$ & $2,19 \pm 1.84$ & 0.561 \\
Insulin resistance & $20 / 33(\% 38.3)$ & $10 / 43(\% 20)$ & $0.031^{\star}$ \\
CIMT & $0.61 \pm 0.12$ & $0.60 \pm 0.13$ & 0.719 \\
Flow baseline diameter (mm) & $3.87 \pm 0.64$ & $3.67 \pm 0.65$ & 0.119 \\
\hline Flow mediated dilation (\%) & $4.04 \pm 5.09$ & $8.26 \pm 7.16$ & $0.001^{\star}$ \\
\hline
\end{tabular}

${ }^{*} \mathrm{p}<0.05$ Carotid artery intimae-media thickness, Homeostasis Model Assessment

\section{DISCUSSION}

Our study clearly showed impaired endothelial function and increased insulin resistance and likelihood of future progress of atherosclerotic vascular disorder in mild to moderate psoriasis of young population. At the same time euthyroid sick syndrome's presence was demonstrated in mild to moderate psoriasis patients for the first time in literature and its contribution to the increment in cardiovascular risk were discussed.

Atherosclerosis is a systemic disease which progresses silently from childhood and appears clinically at middle and older ages. Psoriasis and 
psoriatic arthritis are associated with increased risk of cardiovascular events and cardiovascular mortality. Alongside classic risk factors such as atherosclerosis, the severity of psoriatic skin disease also influences cardiovascular risk in these patients. In both cases, endothelial dysfunction and increased intima-media thickness in the carotid artery are indicators of subclinical cardiovascular disease (12). Therefore, display of early atherosclerotic changes is very important to reduce risk factors. These early changes are an increase in CIMT and artery vasodilator dysfunction (13). CIMT was found to be associated with cardiovascular risk factors and prevalence of symptomatic coronary artery disease (14). In addition, CIMT also increases parallel with an increase in cardiovascular risk factors (15). Although some studies indicate no correlation between carotid CIMT and FMD (16), several others have shown that CIMT was well correlated with FMD (17-19). Also in our study, CIMT was positively correlated with FMD basal artery diameter and negatively correlated with \% FMD. Although CIMT was much more in psoriasis patients than the control group, there wasn't a statistically significant difference between two groups. There are conflicting data especially about CIMT regarding the detection of premature atherosclerosis in relatively young patients with chronic inflammatory disease (20). There wasn't a correlation between CIMT and psoriasis patient group in the present study, this is can be explained by our patients' young average age (average age $37.66 \pm 15.6$ years). There are several studies on FMD in patients with psoriasis. These studies also demonstrated endothelial dysfunction in patients with psoriasis similar to our study $(21,22)$. The difference of present study from others is that we demonstrated endothelial dysfunction in patients with psoriasis with a low disease activity. The relationship between psoriasis and diabetes mellitus (DM) had been demonstrated with large scaled casecontrolled studies in literature (23). Boehncke et al. (24) stated that metabolic situation shifted towards insulin resistance. In another study in which insulin resistance assessed by HOMA-IR formula, psoriasis patients had higher HOMA-IR scores than control group (25). The relationship between psoriasis and endothelial dysfunction and insulin resistance can be explained by the chronic secretion of proinflammatory cytokines like TNF-alpha, IL-1 and IL-6 in psoriasis. Chronic systemic inflammation stimulates endothelial dysfunction and changes glucose metabolism. Insulin resistance plays an important role in the development of atherosclerosis (26). As a result of low-level inflammation in psoriasis patients, especially truncal fat tissue can contribute to the production of adipokine. This results in insulin resistance and endothelial dysfunction (27). Insulin resistance in our psoriasis patient group was compatible with the literature.
There wasn't a convincing explanation for aetiology of dyslipidemia in patients with psoriasis in the literature. However, chronic inflammation is thought to increase dyslipidemia in these patients (28). Li et al's study showed the protective effect of HDL cholesterol on endothelium-dependent vasodilatation (29). Sezgin et al. showed the independent association between HDL and FMD (30). The low level of HDL in our psoriasis patient group might be a contributing factor for the impairment of endothelial function.

Euthyroid sick syndrome is characterized by a decrease in the level of FT3 while FT4 and TSH levels were normal. In our study, patients with mild psoriasis group compared with the control group had significantly lower levels of $\mathrm{FT}_{3}$ in normal rangeCoceani $M$. et al. assessed 1047 people by coronary angiography that suspected coronary artery disease without clinical heart disease, and primary thyroid disease (31). Participants who had lower FT3 levels were associated with coronary artery disease. After follow-up of 31 months, total mortality and cardiac mortality were found to be higher in patients with low $\mathrm{FT}_{3}$. As it is known, dyslipidemia and early development of atherosclerosis in patients with psoriasis is generally described by chronic inflammatory process. Many investigators use experience requiring, time-consuming and relatively high cost, subjective methods such as percentage of FMD, CIMT in order to determine early atherosclerosis as we did in the present study. Thyroid function tests (TFTs) are cheap, not requiring experience and almost available at all clinics. TFTs may also be used as a screening test by doctors easily.

The present study showed that psoriasis patients compared with the control group had impaired FMD dilatation and impaired endothelial function. Besides endothelial dysfunction in psoriasis patients, insulin resistance and dyslipidemia characterized by low HDL also contributed to subclinical atherosclerosis and increased cardiovascular disease risk. Furthermore, TFTs and especially FT3 level is thought to be used as a marker assay in psoriasis patients for early detection of subclinical atherosclerosis. More extensive studies are needed on this subject.

\section{REFERENCES}

1. Schön MP, Boehncke WH. Psoriasis. N Engl J Med 2005; 352:1899-912.

2. Langley RG, Krueger GG, Griffiths CE. Psoriasis: epidemiology, clinical features, and quality of life. Ann Rheum Dis 2005;64:18-23.

3. Lowes MA, Bowcock AM, Krueger JG. Pathogenesis and therapy of psoriasis. Nature 2007;445:866-73.

4. Krueger JG, Bowcock A. Psoriasis pathophysiology: current concepts of pathogenesis. Ann Rheum Dis 2005;64:30-6. 
5. Kaye JA, Li L, Jick SS. Incidence of risk factors for myocardial infarction and other vascular diseases in patients with psoriasis. Brit J Dermatol 2008;159:895-902.

6. Gelfand JM, Neimann AL, Shin DB, Wang X, Margolis DJ, Troxel AB. Risk of myocardial infarction in patients with psoriasis. JAMA 2006;296:1735-41.

7. Wakkee M, Herings RMC, Nijsten T. Psoriasis may not be an independent risk factor for acute ischemic heart disease hospitalizations. Results of a large population-based Dutch cohort. J Invest Dermatol 2010;130:962-67.

8. Mehta NN, Azfar RS, Shin DB, Neimann AL,Troxel AB, Gelfand JM. Patients with severe psoriasis are at increased risk of cardiovascular mortality: cohort study using the general practice research database. Eur Heart J 2010;31:1000-6.

9. Stern RS. Psoriasis is not a useful independent risk factor for cardiovascular disease. J Invest Dermatol 2010;130:917-19.

10. Glagov S, Weisenberg E, Zarins CK, Stankunavicius R, Kolettis GJ. Compensatory enlargement of human atherosclerotic coronary arteries. N Engl J Med 1987;316:1371-75.

11. Aydin Y, Berker D, Ustün I, Gül K, Erden G, Kutlucan A Yilmaz Aydin L, Güler S. Evaluation of carotid intima media thickness in impaired fasting glucose and impaired glucose tolerance. Minerva Endocrinol 2011;36:171-9.

12. González-Gay MA, González-Vela C, González-Juanatey C. Psoriasis: a skin disease associated with increased cardiovascular risk. Actas Dermosifiliogr 2012;103:595-8.

13. Fathi $R$, Marwick TH. Noninvasive tests of vascular function and structure: why andhow to perform them. Am Heart $J$ 2001;141:694-703.

14. Mukherjee D, Yadav JS. Carotid artery intimal-medial thickness: indicator of atherosclerotic burden and response to risk factor modification. Am Heart J 2002;144:753-59.

15. Touboul PJ, Labreuche J, Vicaut E, Belliard JP, Cohen S, Kownator $S$ et al. Country-based reference values and impact of cardiovascular risk factors on carotid intima-media thickness in a French population: the 'Paroi Artérielle et Risque Cardio-Vasculaire' (PARC) Study. Cerebrovasc Dis 2009:27:361-67.

16. Yan RT, Anderson TJ, Charbonneau F, Title L, Verma S, Lonn E. Relationship between carotid artery intima-media thickness and brachial artery flow-mediated dilation in middle-aged healthy men. J Am Coll Cardiol 2005;45:198086.

17. Kobayashi K, Akishita M, Yu W, Hashimoto M, Ohni M, Toba $K$. Interrelationship between non-invasive measurements of atherosclerosis: flow-mediated dilation of brachial artery, carotid intima-media thickness and pulse wave velocity. Atherosclerosis 2004;173:13-18.

18. Campuzano R, Moya JL, Garcia-Lledo A, Tomas JP, Ruiz S Megías $A$ et al. Endothelial dysfunction, intima-media thickness and coronary reserve in relation to risk factors and
Framingham score in patients without clinical atherosclerosis. J Hypertens 2006;24:1581-88.

19. Juonala M, Viikari JS, Laitinen T, Marniemi J, Helenius $H$, Rönnemaa $\mathrm{T}$ et al. Interrelations between brachial endothelial function and carotid intima-media thickness in young adults: the cardiovascular risk in young Finns study. Circulation 2004;110:2918-23.

20. Roman MJ, Shanker BA, Davis A, Lockshin MD, Sammaritano L, Simantov R et al. Prevalence and correlates of accelerated atherosclerosis in systemic lupus erythematosus. N Engl J Med 2003;349:2399-406.

21. Balci DD, Balci A, Karazincir S, Ucar E, lyigun U, Yalcin F et al. Increased carotid artery intima-media thickness and impaired endothelial function in psoriasis. J Eur Acad Dermatol Venereol 2009;23:1-6

22. Gonzalez-Juanatey C, Llorca J, Miranda-Filloy JA, AmigoDiaz E, Testa A, Garcia-Porrua C et al. Endothelial dysfunction in psoriatic arthritis patients without clinically evident cardiovascular disease or classic atherosclerosis risk factors. Arthritis Rheum 2007;57:287-93.

23. Shapiro J, Cohen AD, David M, Hodak E, Chodik G, Viner A et al. The association between psoriasis, diabetes mellitus, and atherosclerosis in Israel: a case-control study. J Am Acad Dermatol 2007;56:629-34.

24. Boehncke S, Thaci D, Beschmann H, Ludwig RJ, Ackermann $\mathrm{H}$, Badenhoop $\mathrm{K}$ et al. Psoriasis patients show signs of insulin resistance. $\mathrm{Br}$ J Dermatol 2007; 157:1249-51.

25. Ucak S, Ekmekci TR, Basat O, Kolsu A, Altuntas Y. Comparison of various insulin sensitivity indices in psoriatic patients and their relationship with type of psoriasis. J Eur Acad Dermatol Venereol 2006;20:517-22.

26. Mehlis SL, Gordon KB. The immunology of psoriasis and biologic immunotherapy. J Am Acad Dermatol 2003;49:44-50.

27. Yudkin JS. Insulin resistance and the metabolic syndrome-or the pitfalls of epidemiology. Diabetoligia 2007;50:1576-86.

28. Sattar N, McCarey DW, Capell H, Mclnnes IB. Explaining how 'high-grade' systemic inflammation accelerates vascular risk in rheumatoid arthritis. Circulation 2003;108:2957-63.

29. Li XP, Zhao SP, Zhang XY, Liu L, Gao M, Zhou OC. Protective effect of high density lipoprotein on endothelium-dependent vasodilatation. Int J Cardiol 2000;73:231-36.

30. Sezgin AT, Barutcu I, Sezgin N, Gullu H, Esen AM, Acikgoz $\mathrm{N}$ et al. Contribution of plasma lipid disturbances to vascular endothelial function in patients with slow coronary flow. Angiology 2007;57: 694-701.

31. Coceani M, lervasi G, Pingitore A, Carpeggiani C, L'Abbate $A$. Thyroid hormone and coronary artery disease: from clinical correlations to prognostic implications. Clin Cardiol 2009:32:380-85

\section{Received/Başvuru: 28.11.2012, Accepted/Kabul: 21.12.2012}

\section{Correspondence/İletişim}

Oğuzhan AKSU

Süleyman Demirel Üniversitesi Tıp Fakültesi , Endokrinoloji ve Metabolizma Hastalıkları Bilim Dalı, ISPARTA/ TÜRKIYE E-mail: drooaksu@yahoo com

\section{For citing/Atıf için:}

Aksu O, Erturan I, Ersoy H.i, Köroğlu K.B, Ermiş F, Korkmaz $S$, Tamer MN. A prospective case-controlled study of endothelial function in patients with mild to moderate psoriasis. J Turgut Ozal Med Cent 2013;20(2):107-112 DOI: 10.7247/jtomc.20.2.3 